\title{
Escherichia coli infection in diabetic and non diabetic albino rats
}

\author{
Abd El Fattah, M; Abd El Razik, M.; Hassan, M. F.; El Emam, G. and \\ Nagwa Ibrahim Mohamed \\ Faculty of Science, Suez Canal University
}

\begin{abstract}
Diabetes mellitus is a potentially morbid condition with high prevalence worldwide thus the disease constitutes a major health concern. The use of experimental models for the disease is imperative. Diabetic rat's organs were adversely affected by bacterial infection. Neisseria sp and E.coli isolated from the heart and liver organs of non-diabetic rats that infected with E.coli. Diabetic and diabetic infected rats with E.coli had Pseudomonas and Bacillius $s p$ in the spleen and kidney organs respectively.
\end{abstract}

\section{Introduction}

According to the World Health organization (WHO) ,there are approximately 160,000 diabetic worldwide, the number of diabetics has double in the last few years and is expected to double once again in the year 2025 (Beretta, 2001) animals models for studying diabetes.

Infectious diseases are more frequent and/or serious in patients with diabetes mellitus, which potentially increases their morbimortality. The greater frequency of infections in diabetic patients is caused by the hyperglycemic environment that favors immune dysfunction (e.g., damage to the neutrophil function, depression of the antioxidant system, and humoral immunity), micro- and macro-angiopathies, neuropathy, decrease in the antibacterial activity of urine, gastrointestinal and urinary dysmotility, and greater number of medical interventions in these patients. The infections affect all organs and systems. Some of these problems are seen mostly in diabetic people, such as foot infections, malignant external otitis, rhinocerebral mucormycosis, and gangrenous cholecystitis. In addition to the increased morbidity, infectious processes may be the first manifestation of diabetes mellitus or the precipitating factors for complications inherent to the disease, such as diabetic ketoacidosis and hypoglycemia. Immunization with antipneumococcal and influenza vaccines is recommended to reduce hospitalizations, deaths, and medical expenses. (Casqueiro et al, 2012)

Over the years, several animal models have been developed for studying diabetes mellitus or testing anti-diabetic agents. These models 
include chemical, surgical (pancreatectomy) and genetic manipulations in several animal species to induce diabetes mellitus. The diabetogenic drugs used include: alloxan monohydrate, streptozotocin with or without nicotinamide , ferric nitrilotriacetate, ditizona and antiinsulin serum.

Alloxan is a well- known diabetogenic agent widely used to induce Type 2 diabetes in animals (Viana et al, 2004). Alloxan is a urea derivative which causes selective necrosis of the pancreatic islet $\beta$-cells. It is used to produce experimental diabetes in animals such as rabbits, rats, mice and dogs. Alloxan selectively destroys beta cells in the pancreas and causes hyperglycemia after 18 hours (Yanarday and Colak, 1998). Diabetes was confirmed by two consecutive daily blood glucose levels greater than $250 \mathrm{mg} / \mathrm{dl}$ (Raffel, 1981)

Experimental models of infections in rabbits, rats, and mice with chemically induced diabetes have shown increased susceptibility to various bacterial and fungal infections (Mukherji and Basu Mallik, 1975). Some studies to the contrary have shown no increased susceptibility to infection (Schofield and Baker, 1956). The present investigation was undertaken to determine the course of experiment.

\section{Material and methods}

Animals: 24 Male albino rats weighing 200-250 g were rendered diabetic by administration of alloxan $(160 \mathrm{mg} / \mathrm{kg})$ intraperitoneally. All animals were maintained on standard rat chow and allowed water ad libitum. Within 10 days after injection of alloxan, animals were divided into four groups (each group had 6 rats), (a) control (non diabetic), (b) diabetic, (c) control infected with E.coli, and (d) diabetic infected E.coli. Blood glucose levels were recorded daily and prior to the time that the animals were sacrificed.

\section{Organism:}

E.coli species, from botany department, science faculty of Ismailia was used in the experiment. This organism has been characterized in details. (Gram reaction, oxidase test, indole test, eosin blue agar EMB agar) (Odds, 1981). All isolates were preserved by sub culturing in nutrient broth and incubating at $37{ }^{\circ} \mathrm{C}$ for $18 \mathrm{~h}$. half $\mathrm{ml}$ of bacterial suspension was prepared for injection intraperitoneally into the rats.

Preparation of samples and culture technique:

Spleen, gut, liver, kidney and heart organs were collected from the experimental animals after killing under complete aseptic conditions. Samples were rinsed in phosphate buffered saline to remove non adherent bacteria and processed for culturing. The microbial recovery was expressed as the $\log ^{10}$ colony forming units $(\mathrm{c} \mathrm{f} \mathrm{u}) / \mathrm{g}$ tissue wet 
weight (Roza et al, 1992). The plates were inspected after 24 hours and all isolates were characterized by standard methods (Hale et al, 1976). The individual isolates were initially characterized by colonial morphology and Gram reaction.

Statistics: one-way ANOVA test.

\section{Results}

There are poly-microbial infections with gram positive and negative bacteria in the experimental groups in the study.

Spleen had more frequent site of infection for the gram negative bacteria. Heart, at the opposite, had least frequent for infection for both kinds of bacteria as shown in Table 1. Gut and kidney had also both kinds of gram stain bacteria (positive and negative).

E.coli ( gram negative bacilli) was isolated from the liver of control rats infected with E.coli group Table 2. That group had Neisseria sp (gram negative cocci) from the heart organ. The diabetic one had Pseudomonas (gram negative bacilli) in the spleen. The diabetic rat infected with E.coli had Bacillius sp (gram positive bacilli spore forming-aerobic).

In the gut of diabetic and diabetic infected with E.coli rats have a significant increase (0.008) in microbial infection. The spleen, liver, and kidney have also significant increase in the microbial count, $\quad(0.002, \quad 0.004,0.015)$ compared to control. There no significant increase between groups in case of heart as shown in Table 3. The values represent the mean \pm SEM for seven animals in each group. Comparisons were made by one-way ANOVA test. Mean log 10 CFU $\mathrm{g}^{-1}$ of tissue \pm SEM. (a)= $\mathrm{P}<0.05$ compared to control rats. (b) $=\mathrm{P}<0.01$

Table 1: Gram positive and negative bacteria recovered from infected organs.

\begin{tabular}{|l|c|c|}
\hline \multicolumn{1}{|c|}{ Group } & Gram (+) Site of infection & Gram (- )Site of infection \\
\hline Control & ------- & ------- \\
\hline Control+E.coli & Kidney, liver & Liver ,spleen ,heart \\
\hline Diabetic & liver & Spleen, gut ,liver \\
\hline Diabetic + E.coli & Gut ,kidney & Spleen, kidney \\
\hline
\end{tabular}


Table 2: Bacterial species found in organs of experimental groups of animals

\begin{tabular}{|l|c|c|}
\hline \multicolumn{1}{|c|}{ group } & Organ & Bacterial species \\
\hline Control & 0 & 0 \\
\hline \multirow{2}{*}{ Control+E.coli } & liver & E.coli \\
\cline { 2 - 3 } & Heart & Neisseria $s p$ \\
\hline \multirow{2}{*}{ Diabetic } & spleen & Pseudomonas \\
\hline Diabetic +E.coli & kidney & Bacillius $s p$ \\
\hline
\end{tabular}

Table 3: the mean value of bacteria content in organs of different experimental groups infected or not infected with E. coli $\left(\log 10 \mathrm{CFU} \mathrm{g}^{-1}\right)$

\begin{tabular}{|c|c|c|c|c|c|}
\hline & $\begin{array}{c}\text { Normal } \\
\text { control }\end{array}$ & $\begin{array}{c}\text { Control rats } \\
\text { Infected } \\
\text { with E.coli }\end{array}$ & $\begin{array}{c}\text { Diabetic rats } \\
\text { infected with } \\
\text { E.coli }\end{array}$ & Diabetic & $\begin{array}{c}\text { Between } \\
\text { group sig. }\end{array}$ \\
\hline Heart & $0.00 \pm 0.00$ & $7.5 \pm 3.5$ & $0.01 \pm 0.0$ & $0.01 \pm 0.0$ & 0.09 \\
\hline Liver & $0.00 \pm 0.00$ & $0.00 \pm 0.00$ & $0.00 \pm 0.00$ & $2.5 \pm 0.7$ & $0.004(\mathrm{~b})$ \\
\hline Spleen & $0.00 \pm 0.00$ & $9.5 \pm 0.7$ & $3 \pm 1.4$ & $9 \pm 1.4$ & $0.002(\mathrm{~b})$ \\
\hline Kidney & $0.00 \pm 0.00$ & $5.5 \pm 0,004$ & $8.5 \pm 0.014$ & $0.01 \pm 0.0$ & $0.015(\mathrm{a})$ \\
\hline Gut & $0.00 \pm 0.00$ & $0.01 \pm 0.0$ & $3.5 \pm 0.7$ & $4.5 \pm 0.7$ & $0.008(\mathrm{~b})$ \\
\hline
\end{tabular}

\section{Discussion:}

Diabetes mellitus (DM) is a clinical syndrome associated with deficiency of insulin secretion or action. It is considered one of the largest emerging threats to health in the $21^{\text {st }}$. It is estimated that there will be 380 million persons with DM in 2025. (Restrepo et al, 2011). Besides the classical complications of the disease, DM has been associated with reduced response of $\mathrm{T}$ cells, neutrophil function, and disorders of humoral immunity (Geerlings and Hoepelman, 1999; Muller et al, 2005 and Peleg et al, 2007). Consequently, DM increases the susceptibility to infections, both the most common ones as well as those that almost always affect only people with DM (e.g. rhinocerebral mucormycosis) (Peleg et al, 2007). Such infections, in addition to the repercussions associated with its infectivity, may trigger DM complications such as hypoglycemia and ketoacidosis. Several infectious diseases are strongly associated with diabetes, whereas others are more complicated or severe in the presence of diabetes. Patients with diabetes appear to be at greater risk for a number of different kinds of 
infections (Paauw, 2000). The association of DM and infection by Helicobacter pylori is controversial. The efficiency of $H$. pylori eradication is lower in persons with DM, whereas the re-infection rates are seen to be higher (Schimke et al, 2009; Papamichael et al, 2009 and Ojetti et al, 2010). The most common etiological agent is Candida albicans. (Peleg et al, 2007 and Menezes et al, 2007) in oral infection of diabetes .Its pathogenesis is related to a combination of factors that increase its virulence, with emphasis on the production of extracellular enzymes such as proteinase and phospholipase (Menezes et al, 2007).

Chen et al (2005) analyzed 72 patients, who were diagnosed as having E. coli liver abscesses, and found that the overall mortality rate was $26.4 \%$. The majority of $E$. coli liver abscesses was solitary, involved the right lobe of the liver, and comprised polymicrobial infections. The cause of the liver abscess involved the biliary system in 48 patients $(66.7 \%)$. The most common concomitant diseases were diabetes mellitus $(30.6 \%)$ and underlying malignancy (30.6\%). Renal infection in diabetic rats and diabetic that infected with the bacterium $E$. coli has more microbial count. Finding in this study suggest that diabetic kidney is more susceptible to reinfection by the ascending route as Raffel $\boldsymbol{e t}$ al (1981) who found that an increased size or infectivity of the urinary S.aureus or Candida population. Raffel et al (1981) said that decreased antimicrobial activity in diabetic urine due to the presence of glycosuria or dilution of inhibitory substances also found that Enterococci which grew equally well in urine from diabetic and nondiabetic rats caused equally sustained renal infection. Suppression of cell- mediated immunological reactivity has been reported in both diabetic mice (Mahmoud et al, 1976) and in nondiabetic rats with experimental Escherichia coli pyelonephritis (Miller et al, 1978 and Wrilliams et al, 1976). Microbial metabolism within the gastrointestinal dependent growth within virtually all microbial populations is stimulated by glucose availability. It is likely that in untreated diabetes there is a constant overabundance of glucose. Constant unmodified increased availability of substrate would be expected to result in bacterial over growth and shifts in microbial populations (Roza et al, 1992). Both diabetes and liver cirrhosis predisposed patients to serious bacterial infection. Spontaneous ascitic fluid infection is usually caused by an enteric bacterium, such as Escherichia coli or Klebsiella species (Figueras et al, 2000). Patients with diabetes have elevated rates and severity of $K$. pneumoniae infections, including pneumonia, bacteremia, hepatic abscess, and meningitis (Feldman 
et al, 1990 ; Han 1995 and Tang et al, 1997).

\section{References}

Casqueiro J, Casqueiro J, and Alves C (2012): Infections in patients with diabetes mellitus: A review of pathogenesis. Indian $\mathrm{J}$ Endocrinol Metab. Mar 16(Suppl1): S27-S36.

Chen S C, Yen C H, Lai K C, Tsao S M, Cheng K S, Chen C C, Lee $M C$ and Chou $M C$ (2005): Pyogenic liver abscesses with Escherichia coli: etiology, clinical course, outcome, and prognostic factors. Wien Klin Wochenschr. Dec; 117 (23-24):809-15.

Feldman C, Smith C, Levy H, Ginsburg P, Miller S D and Koornhof H J.(1990): Klebsiella pneumoniae bacteraemia at an urban general hospital. J Infect. 20: 21-31.

Figueras MJ, Guarro J, and Murcia A M (2000): Klebsiella pneumoniae Necrotizing Fasciitis Associated with Diabetes and Liver Cirrhosis. CID;30 (June).

Geerlings SE and Hoepelman AI (1999): Immune dysfunction in patients with diabetes mellitus (DM) FEMS Immunol Med Microbiol. 26:256-65.

Hale J E , Perinpanaygam R M and Smith G(1976): Bacteroides: an unusual cause of breast abscess. Lancet, 2:70-1.

Han SH (1995): Review of hepatic abscess from Klebsiella pneumoniae: an association with diabetes mellitus and septic endophthalmitis. West J Med. 162:220-4.

Mahlmoud, A.AF,Cheever AW, and Warren KS.(1975):

Streptozotocin-induced diabetes mellitus and the host-parasite relation in murine schistosomiasis mansoni. J. Infect. Dis. 131:634642.

Mahmoud, A. A. F., Rodman H. M., Mandel M. A., and Warren K. S. (1976): Induced and spontaneous diabetes mellitus and suppression of cell-mediated immunologic responses. J. Clin. Invest. 57:362-367. Menezes EA, Augusto KL, Freire CC, Cunha FA, Montenegro RM, and Montenegro-Júnior RM (2007): Frequency and enzymatic activity of Candida spp.oral cavity of diabetic patients of the service of endocrinology of a hospital of Fortaleza-CE. J Bras Patol Med Lab. 43:241-4.

Miller T., Scott L, Stewart E, and North D. (1978): Modification by suppressor cells and serum factors of the cell-mediated immune response in experimental pyelonephritis. J. Clin. Invest. 61:964-972.

Muller LM, Gorter KJ, Hak E, Goudzwaard WL and Schellevis FG, (2005): Increased risk of common infections in patients with type 1 and type 2 diabetes mellitus. Clin Infect Dis. 41:281-8.

Mukherji, A. K., and Basu Mallik K. C. (1975): Candida albicans infection in alloxan induced 
diabetic mice. Indian J. Med. Res. 63:539-544.

Odds FC (1981): Biochemical Tests for Identification of Medical Bacteria. J Clin Pathol. 34: 572.

Ojetti V, Pellicano R, Fagoonee S, Migneco A, Berrutti $M$ and Gasbarrini A (2010): Helicobacter pylori infection and diabetes. Minerva Med.101:115-9.

Paauw D S (2000): Infectious emergencies in patients with diabetes. Clinical Diabetes . Vol. 18 No. 3 Summer.

Peleg AY, Weerarathna T, McCarthy JS and Davis TM (2007): Common infections in diabetes: Pathogenesis, management and relationship to glycaemic control. Diabetes Metab Res Rev. 23:3-13.

Raffel L , Pitsakis P, Levison S $P$, and Levison A E (1981): Experimental Candida albicans, Staphylococcus aureus, and Streptococcus faecalis pyelonephritis in diabetic rats. Infection and Immunity, Dec. p. 773-779.

Papamichael KX, Papaioannou G, Karga H, Roussos A and Mantzaris GJ( 2009): Helicobacter pylori infection and endocrine disorders: is there a link.? World J Gastroenterol. 15:2701-7. Schimke K, Chubb SA, Davis WA, Philipst $P$ and Davis TM (2009): Antiplatelet therapy, Helicobacter pylori infection and complicated peptic ulcer disease in diabetes: The fremantle diabetes study. Diabet Med. 26:70-5.
Restrepo BI, Camerlin AJ, Rahbar MH, and Wang W (2011): Cross-sectional assessment reveals high diabetes prevalence among newly-diagnosed tuberculosis cases. Bull World Health Organ. 89:352-9.

Roza AM ,Edmiston CE and Frantzides C (1992): Untreated diabetes mellitus promotes intestinal microbial overgrowth. The American journal of surgery. Vol. 163. April .

Schofield, R. A., and Baker R. D (1956):

Experimental mucormycosis (rhizopus infection) in mice: failure of chronic alloxan diabetes mellitus to modify host susceptibility. Arch. Pathol. 61:407415.

Tang LM, Chen ST, Hsu WC and Chen CM (1997): Klebsiella meningitis in Taiwan: an overview. Epidemiol Infect.119: 135-42. Wrilliams, T. W., Friedlander A. M., Lyons J. M., and Braude A. L.(1976): Cellular immunity in pyelonephritis: identification of suppressor cell activity of spleen cells in response to concanavalin A and inhibition of lymphocytemediated L cell cytotoxicity. J. Immunol. 116:778-781.

Yanarday R and Colak H.(1998): Effect chard (Beta vulgaris L. varcicla ) on blood glucose level in normal and alloxan-induced diabetic rabbit.J.Ethnopham.4:309311. 
بكتريا الايشرشيا كولاى فى فئران التجارب المصابة وغير المصابة بمرض السكرى

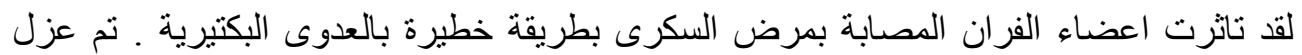

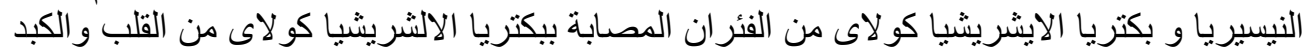

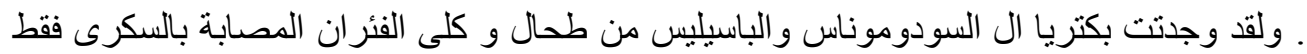
و المصابة بالسكرى و البكتريا بالترتيب. 